\title{
VERTICAL DISTRIBUTION OF ARCHAEAL COMMUNITIES IN COLD SEEP SEDIMENTS FROM THE JIULONG METHANE REEF AREA IN THE SOUTH CHINA SEA
}

\author{
DISTRIBUIÇÃO VERTICAL DA COMUNIDADE ARCHAEAL EM ZONA DE \\ EMANAÇÃO FRIA NA ÁREA DO RECIFE DE METANO DE JUILONG, NO SUL DO \\ MAR DA CHINA
}

\author{
Hongpeng CUI ${ }^{1,2}$; Xin $\mathrm{SU}^{1,2}$; Fang $\mathrm{CHEN}^{3}$; Shiping $\mathrm{WEI}^{2}$; Sihai $\mathrm{CHEN}^{3}$; Jinlian WANG ${ }^{3}$ \\ 1. State Key Laboratory of Biogeology and Environmental Geology, China University of Geosciences, Beijing 100083, China. \\ xsu@cugb.edu.cn; 2. School of Marine Sciences, China University of Geosciences, Beijing 100083, China. weishiping@cugb.edu.cn; \\ 3. Guangzhou Marine Geological Survey, Guangzhou 510075, China.
}

\begin{abstract}
Jiulong methane reef, a large cold seep area on the continental slope of the South China Sea (SCS), was characterized by chemosynthetic fauna, bacterial mats, methane-derived carbonate structures, and a shallow depth of sulfate-methane transition zone (SMTZ) in gravity cores. To characterize the microbial diversity and variation in correlation to methane venting in the cold seep area, the archaeal community in sediments of the gravity Core CL11 was analyzed, using the Illumina MiSeq sequencing system. A total of 96,917 valid sequences were obtained and classified into 275 OTUs. Taxonomic analysis showed that all the archaeal sequences belonged to the phyla of Crenarchaeota $(69.41 \%)$ and Eurarchaeota (25.26\%). Vertical distribution of the archaeal communities showed that the Marine Benthic Group B (MBGB) was the predominant group (58.92\%) in the topmost sediment of the core, while percentages of the South African Gold Mine Euryarchaeotal Group (SAGMEG) sequences increased with depth. Our findings indicate that the archaeal community in the cold seep of Jiulong Methane Reef is unique and provides us new insights into the archaeal community composition of the cold seep area.
\end{abstract}

KEYWORDS: Depth. Diversity. Sulfate-methane Transition Zone.

\section{INTRODUCTION}

Cold seeps represent one of the most extreme marine conditions and are characterized by fluids seepage into surface sediments, causing elevated methane and/or sulfide concentrations over those of ambient seawater, thus forming oases of elevated microbial biomass and various faunal assemblages on the seafloor. The first cold seep ecosystem was discovered on the Florida Escarpment in the Gulf of Mexico (PAULL et al 1984). Since then, seeps have been discovered in other parts of the world's oceans. Research revealed that biota in the cold seeps rely on chemoautotrophy, especially those bacteria metabolizing methane and hydrogen sulfide for energy.

Previous studies showed that microbial communities often thrive at cold seep sites, which sustain distinctive geochemical and microbial processes. It was demonstrated that methanotrophic archaea carry out a process called anaerobic oxidation of methane (AOM), initiating the living processes of growth, reproduction and energy flow to make other organisms' existence possible. Considerable research of archaeal communities has been conducted in different typological cold seep areas around the world, such as Hydrate Ridge
(KNITTEL et al 2005), Nankai Trough (ARAKAWA et al 2006), Tropical Timor Sea (WASMUND et al 2009), Northern South China Sea (Northern SCS) (ZHANG et al 2012), and Sonora Margin (VIGNERON et al 2013). These studies showed that different cold seep areas harbored different archaeal communities. Phylogenetic analysis of archaeal community revealed that anaerobic methane oxidation group (ANMEs) and MBG-D were detected at Hydrate Ridge (KNITTEL et al 2005), whereas the archaeal phylotypes were mainly composed of Marine Group I (MGI), Miscellaneous Crenarchaeotic Group (MCG) and MBG-B in the tropical Timor Sea methane seep (WASMUND et al 2009). A report from Zhang et al. (2012) showed that MBG-B and Halobacteria were dominant archaeal groups in cold seep sediment from the Northern SCS, whereas ANMEs dominated the archaeal community in the Sonora Margin cold seep ecosystem (VIGNERON et al 2013). A significant differences in microbial activity among the different seep systems were observed when comparing the rates of AOM and sulfate reduction (SR). Even though high concentrations of methane and sulfate are available, the methanotrophic microbial activity and biomass 
may be low for unknown reasons in some seep environments.

In this study, a gravity sediment core was collected from the southern slope of Jiulong methane reef in the SCS. The analyses of sedimentary microbial community by pyrosequencing allowed us to determine the archaeal diversity and downcore variation coupled to the environmental parameters.

\section{MATERIAL AND METHODS}

\section{Site description and sampling}

Jiulong methane reef, located on the northern continental slope of the SCS, is the first cold seep area discovered by the joint ChineseGerman RV Sonne cruise 177 in 2004 (SUESS et al
2005). It was characterized by chemosynthetic fauna and bacterial mats, methane-derived carbonate structures, and a very shallow depth of the SMTZ in gravity cores. Evidence of active cold vents in this area were reported (ZHANG et al 2012). The gravity Core CL11 (767 cm in length, water depth of $1607 \mathrm{mbsf}$ ) was collected from the southern slope of Jiulong methane reef during a cruise of the Chinese research vessel "Haiyang 4" for geological survey of gas hydrate in SCS in the summer of 2012 (Figure 1). The core was immediately cut into sections of length $30 \mathrm{~cm}$ onboard, and the topmost 3 $\mathrm{cm}$ interval of each section was cut and preserved in liquid nitrogen. The samples were kept frozen and at the end of the trip transported to the Geomicrobiology Laboratory of China University of Geosciences (Beijing) for microbial analyses.

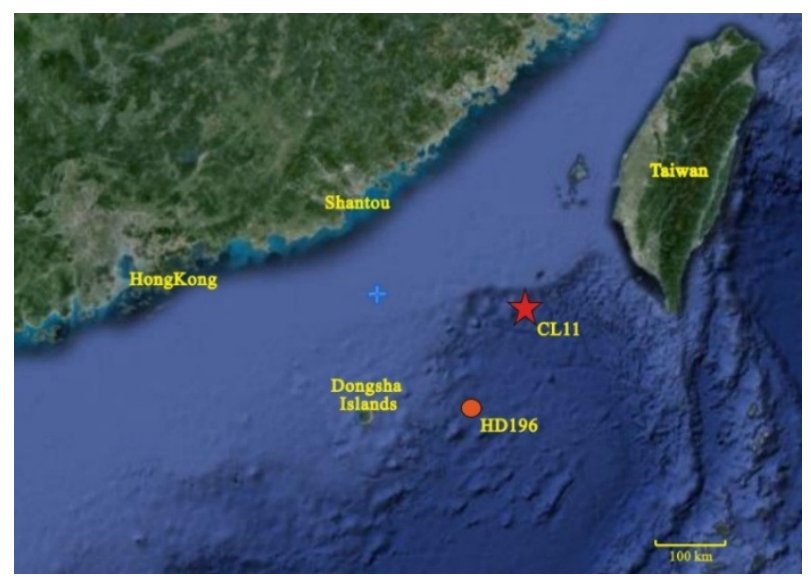

Figure 1. Location of Core CL11 (marked by red star) in the northern SCS.

\section{Geochemical and sedimentary analyses}

Granulometric analysis of sediments was measured using a Mastersizer 2000 laser particle size analyzer following the manufacturer's instructions in the laboratory of Guangzhou Marine Geological Survey. The sediment porosity was determined as Ma et al. (2013) described. Total organic carbon (TOC) content was determined according to the Jiao et al. (2015) protocol using a Multi N/C 2100 Analyzer. Headspace methane concentration was measured by a gas chromatography mass spectrometry as previously described Deng et al. (2006).

\section{Microbial cell and archaeal DNA abundance analysis}

Total microbial cells from the samples were enumerated using the method of acridine orange staining as previously described by Bottomley (1994). Archaeal 16S rRNA gene copies were subjected to quantitative PCR (qPCR) analysis using an ABI 7500 real-time PCR system (Applied
Biosystems, USA). The standards for archaeal $16 \mathrm{~S}$ rRNA genes were prepared from the total community DNA amplified using primers of Arch21F/Arch958R (DELONG et al 1992). The amplicons were made into serial dilutions at 1:10 as the templates to generate a standard curve for total archaeal 16S rRNA genes. The plots of CT versus standard DNA concentration yielded the linear relationship with $\mathrm{R}^{2}$ values greater than 0.99 . PCR was performed in a total volume of $20 \mu \mathrm{L}$ mixture, which containing $10 \mu \mathrm{L}$ of SYBR Premix Ex Taq (TaKaRa, Japan), $1 \mu \mathrm{L}$ of DNA, 10 pmol of each primer, 10 pmol ROX Reference Dye II and appropriate volume of $\mathrm{ddH}_{2} \mathrm{O}$. PCR amplification were performed at 1 cycle of $95{ }^{\circ} \mathrm{C}$ for $30 \mathrm{~s}$, followed by 40 cycles of $95^{\circ} \mathrm{C}$ for $5 \mathrm{~s}, 60^{\circ} \mathrm{C}$ for 34 $\mathrm{s}$. Triplicates of each sample was performed qPCR to determine the $16 \mathrm{~S}$ rRNA gene copies.

\section{DNA isolation and PCR amplification}

Seven sediment subsamples CL11-1 (17 cmbsf), CL11-8 (164 cmbsf), CL11-18 (364 cmbsf), 
CL11-26 (524 cmbsf), CL11-32 (644 cmbsf), CL1137 (744 cmbsf), CL11-38 (764 cmbsf) were selected and subjected to microbial community and geochemical analyses. The total community DNA was extracted from each sample using the Soil DNA Isolation Kit (MP) following the manufacturer's instruction. The extracted DNA was quantified by Nanodrop (Thermo Scientific, NanoDrop ND-1000) and visualized on a $1 \%$ agarose gel using ethidium bromide staining. The archaeal 16S rRNA genes were amplified by PCR $\left(94{ }^{\circ} \mathrm{C}\right.$ for $5 \mathrm{~min}$, followed by 32 cycles at $94{ }^{\circ} \mathrm{C}$ for $30 \mathrm{~s}, 55^{\circ} \mathrm{C}$ for $30 \mathrm{~s}$, and $72{ }^{\circ} \mathrm{C}$ for $2 \mathrm{~min}$ and a final extension at $72{ }^{\circ} \mathrm{C}$ for 10 min) using primers of $751 \mathrm{~F}$ and $1204 \mathrm{R}$ (BAKER et al 2003). PCR reactions were performed in triplicate. A total volume of $20 \mu \mathrm{L}$ mixture was containing $4 \mu \mathrm{L}$ of $5 \times$ FastPfu buffer, $2 \mu \mathrm{L}$ of 2.5 $\mathrm{mM}$ dNTPs, $0.8 \mu \mathrm{L}$ of each primer $(5 \mu \mathrm{M}), 0.4 \mu \mathrm{L}$ of FastPfu polymerase, and 10ng of template DNA.

\section{Sequencing and Bioinformatics}

Amplicons were cut from 2\% agarose gels and purified using the AxyPrep DNA Gel Extraction Kit (Axygen Biosciences, Union City, CA, U.S.) according to the manufacturer's instructions and quantified using QuantiFluor ${ }^{\mathrm{TM}}$-ST (Promega, U.S.). The purified amplicons were pooled in equimolar and paired-end sequenced $(2 \times 250)$ on an Illumina MiSeq platform (Shanghai, China) according to the standard protocols. The raw reads were deposited into the NCBI Sequence Read Archive (SRA) database (Accession Number: PRJNA285416).
Raw fastq files were demultiplexed, qualityfiltered using QIIME (version 1.17) with the following criteria: (i) The 250 bp reads were truncated at any site receiving an average quality score $<20$ over a $10 \mathrm{bp}$ sliding window, discarding the truncated reads that were shorter than 50bp. (ii) Exact barcode matching, 2 nucleotide mismatch in primer matching, reads containing ambiguous characters were removed. (iii) Only sequences that overlap longer than $10 \mathrm{bp}$ were assembled according to their overlap sequence. Reads which could not be assembled were discarded. Operational Taxonomic Units (OTUs) were clustered with $97 \%$ similarity cutoff using UPARSE (version 7.1) and chimeric sequences were identified and removed using UCHIME. The phylogenetic affiliation of each 16S rRNA gene sequence was analyzed by RDP Classifier against the SILVA (SSU115) 16S rRNA database using confidence threshold of $70 \%$ (AMATO et al 2013). Program MOTHUR was used to calculate the Shannon and Simpson diversity indices, and the bias corrected Chao1 (SCHLOSS et al 2009).

\section{RESULTS}

\section{Sedimentary parameters}

The grain size analysis showed that sediments of Core CL11 are mainly composed of silt (68.49-78.53\%), sand $(0-2.06 \%)$ and clay (20.85-31.51\%). A relatively higher percentage of sand and lower percentage of clay occurred in the upper interval (90-440 cmbsf) of the core. The sorting coefficient of sediments varied from 1.33 to 1.58 , indicating that sediments grains were generally well-sorted (Figure 2).

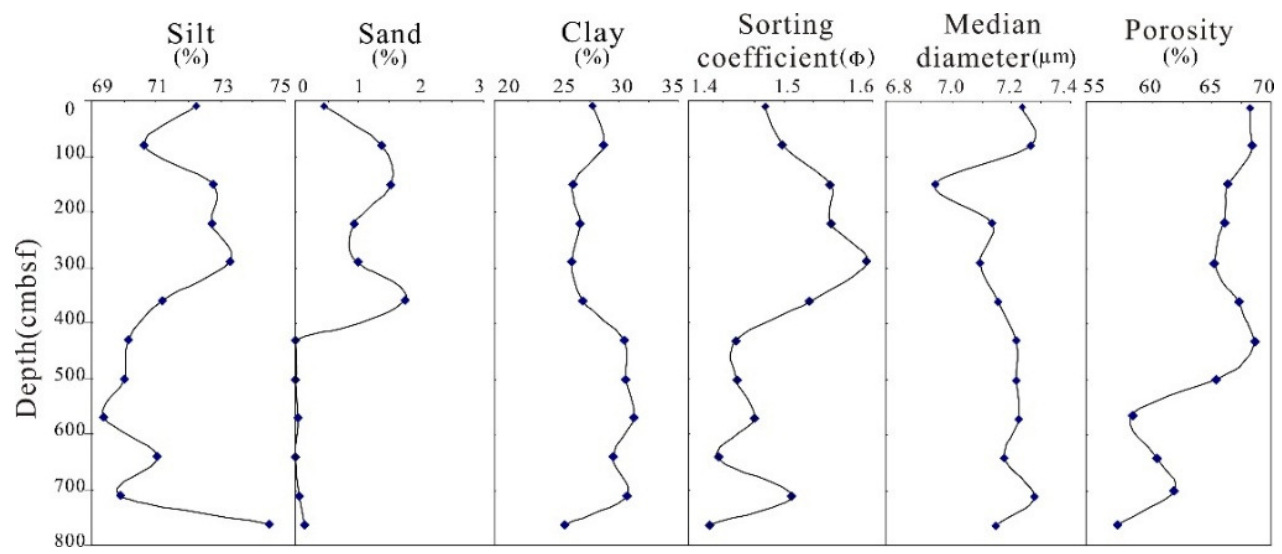

Figure 2. Downcore variation of sedimentary parameters in the Core CL11.

The sedimentary porosities were higher ( $>65 \%$ ) above the depth of $550 \mathrm{cmbsf}$ than that in the lower part of the core. The vertical variation of porosity was apparently correlated with the abundance of sand and clay in the sediments (Figure 2). This result agrees with Patrick et al. (2007), which found that sediment porosity for shallow and unconsolidated sediments is mainly correlated to abundances of sand and coarser silt, and then to fractional-packing type of these coarse grains. 


\section{Geochemical parameters and SMI determination}

Downcore geochemical parameter analysis showed that TOC content slightly increased with the depth ranging from $0.8 \%$ to $1.2 \%$ along the Core CL11. This result was similar with $\mathrm{Su}$ et al. (2005) reported in the Dongsha area. They found that the TOC content was usually higher than $0.8 \%$ in sediments, based on a summary of TOC data from more than 150 sites in the SCS. The sedimental methane concentration was too low to be detected from the top of the core down to the depth of 650 cmbsf. However, a significantly increasing methane concentration was detected at the depths of $744 \mathrm{cmbsf}$
CUI, H.; et al.

and 764 cmbsf (Figure 3a), indicating a methane seepage occurred below the sediment. A similar result was observed from a nearby located gravity Core HD196 (Figure 3b) (DENG et al 2006), in which a clear SMTZ was observed between the depths of 600 to 800 cmbsf with a sharp decrease in sulfate concentration and an increase in methane concentration. Although we did not assay the dissolved sulfate of pore water in this gravity core, we may infer that the sharply increase of $\mathrm{CH}_{4}$ at the nearly bottom of the core is roughly representative of a sulfate-methane transition zone.
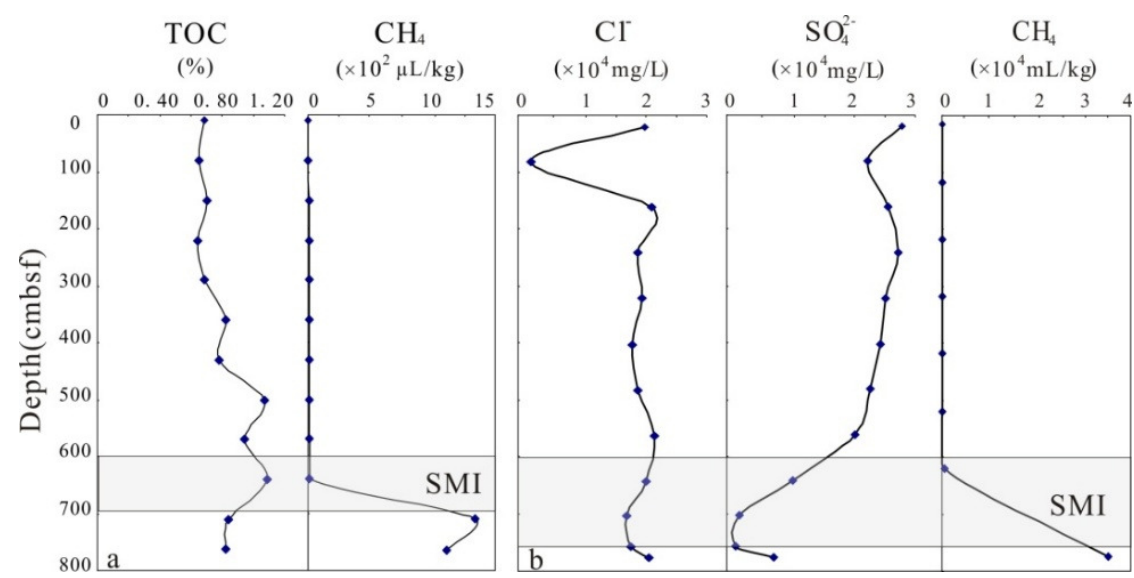

Figure 3. Downcore geochemical parameters of Core CL11 (a) and Core HD196 (b) (DENG et al 2006).

\section{Vertical variation of microbial abundance}

Downcore microbial analysis indicated that the microbial cell abundance varied from $2.13 \times 10^{7}$ to $10.47 \times 10^{7}$ cells/g (Figure 4). A relative higher abundance was observed at the depth of $17 \mathrm{cmbsf}$, $450 \mathrm{cmbsf}$ and $740 \mathrm{cmbsf}$ of the Core CL11. The high cell abundance at the surface sediment of the deep sea samples agreed with previous reports (ZHANG et al 2012). The higher abundance in the middle and bottom intervals of the core is still unexplained, though it was inferred to be related to the specific environments. Total archaeal 16S rRNA gene copies estimated by $\mathrm{qPCR}$ varied from $1.64 \times 10^{7}$ to $3.57 \times 10^{7}$ copies/g and had a similar pattern as the microbial cell abundance (Figure 4). These data implied that archaea constituted a significant proportion of the microbial community.

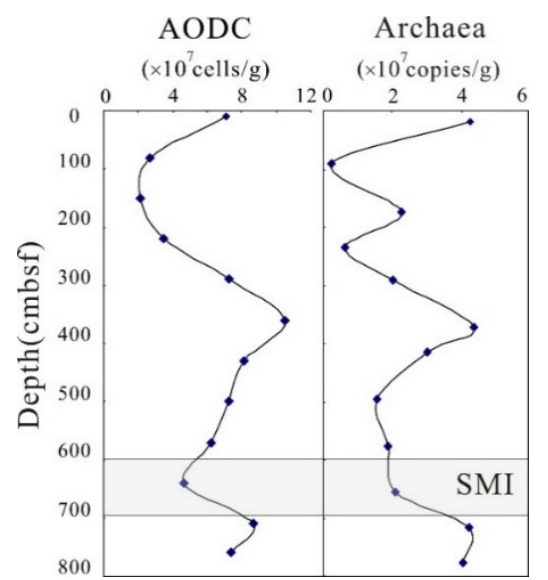

Figure 4. Downcore variation in abundance of microbial cell abundance and archaeal 16S rRNA gene copies in the Core CL11. 


\section{Sequencing analysis}

A total of 101,115 reads were generated from seven samples. After filtering 96,917 highquality sequences, nearly $95.85 \%$ of total reads were used for pyrosequencing analysis. Each library contained 9,996 to 18,676 valid reads (Table 1). A total of 275 OTUs were obtained with an average of OTUs ranging from 33 to 207 per sample based on $\geq 97 \%$ nucleotide sequence identity between reads. The number of OTUs differed significantly between the samples, with a higher number of OTUs detected in the upper core and decreasing numbers in the lower core. This result was also consistent with the alpha diversity analysis, which showed that the Shannon and Simpson indices varied with sediment depth, indicating a different alpha community and composition at different depths. Generally, a trend of decreasing diversity with sediment depths was apparent with rarefaction and OTUs number analyses.

Table 1: Sequencing information and diversity estimates for each sample.

\begin{tabular}{|c|c|c|c|c|c|c|c|}
\hline Sample & cmbsf & Reads & OTUs & Coverage & Chao & Shannon & Simpson \\
\hline $\begin{array}{c}\text { CL11- } \\
1\end{array}$ & 17 & 18676 & 129 & 99.94 & $\begin{array}{c}136(131, \\
157)\end{array}$ & $\begin{array}{c}2.52(2.5 \\
2.54)\end{array}$ & $\begin{array}{c}0.1744(0.1701, \\
0.1788)\end{array}$ \\
\hline $\begin{array}{c}\text { CL11- } \\
8\end{array}$ & 164 & 16120 & 207 & 99.94 & $\begin{array}{c}210(208, \\
219)\end{array}$ & $\begin{array}{c}3.89(3.86, \\
3.91)\end{array}$ & $\begin{array}{c}0.0401(0.0391 \\
0.0412)\end{array}$ \\
\hline $\begin{array}{c}\text { CL11- } \\
18\end{array}$ & 364 & 10204 & 167 & 99.78 & $\begin{array}{c}181(172, \\
205)\end{array}$ & $\begin{array}{c}3.61(3.58, \\
3.64)\end{array}$ & $\begin{array}{c}0.0534(0.0515 \\
0.0553)\end{array}$ \\
\hline $\begin{array}{l}\text { CL11- } \\
26\end{array}$ & 524 & 13859 & 148 & 99.81 & $\begin{array}{c}167(155, \\
198)\end{array}$ & $\begin{array}{c}2.75(2.72, \\
2.78)\end{array}$ & $\begin{array}{c}0.1386(0.1347 \\
0.1425)\end{array}$ \\
\hline $\begin{array}{l}\text { CL11- } \\
32\end{array}$ & 644 & 17579 & 126 & 99.93 & $\begin{array}{c}133(128, \\
154)\end{array}$ & $\begin{array}{c}2.71(2.69, \\
2.74)\end{array}$ & $\begin{array}{c}0.1335(0.1305 \\
0.1366)\end{array}$ \\
\hline $\begin{array}{c}\text { CL11- } \\
37\end{array}$ & 744 & 10483 & 59 & 99.92 & $\begin{array}{c}64(60) \\
82)\end{array}$ & $\begin{array}{c}2.38(2.35 \\
2.4)\end{array}$ & $\begin{array}{c}0.1549(0.1507 \\
0.1592)\end{array}$ \\
\hline $\begin{array}{c}\text { CL11- } \\
38 \\
\end{array}$ & 764 & 9996 & 33 & 99.97 & $\begin{array}{c}34(33 \\
44)\end{array}$ & $\begin{array}{c}2.31(2.29 \\
2.33)\end{array}$ & $\begin{array}{c}0.144(0.1404 \\
0.1476)\end{array}$ \\
\hline
\end{tabular}

\section{Composition of Archaeal Communities}

Two phyla, Crenarchaeota and Eurarchaeota, were detected across sediment samples. Relative abundance of Crenarchaeota (69.41\%) was nearly equal to the phylum of Eurarchaeota (25.26\%). The retrieved crenarchaeal sequences were classified into four lineages, comprised of MBG-B (28.17\%), MCG (23.36\%), C3 (11.84\%) and MGI (6.04\%). Within the phylum of Euryarchaeta, six lineages were detected, including SAGMEG (17.37\%), Thermoplasmatales (3.65\%), Halobacteriales (3.26\%), MBG-E (0.06\%), Mathanomicrobia (0.91\%), ANME-1 $(0.01 \%)$ and unclassified sequences $(5.33 \%)$. The two minor groups of Methanomicrobia and ANME-1 were thought to be related to methane oxidation in anaerobic conditions.

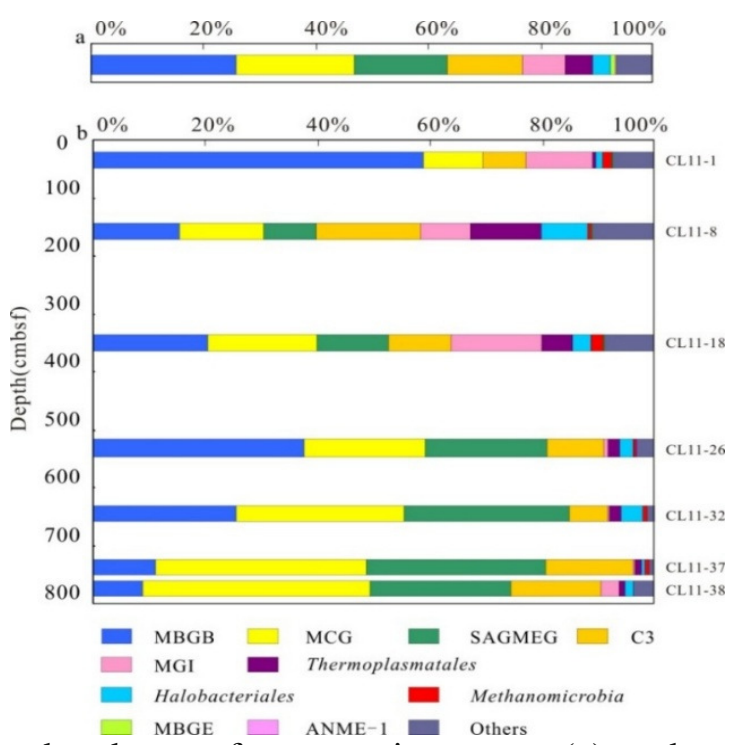

Figure 5. Relative abundance of taxonomic groups (a) and archaeal community compositions (b) in the sediments of Core CL11. 
The depth profile of archaeal community showed clear community changes with depth (Figure $5 b)$. Altogether, three lineages, MBG-B, MCG and SAGMEG, comprised $68.9 \%$ (66,777 sequences) of the archaeal communities, and these three were the dominant groups across all seven sediment depths. Among these, MBG-B occurred in the highest abundance, accounting for $58.9 \%$ (11,003 sequences) of the total sequences occurring in the topmost layer of the sediment, then MBG-B decreased significantly with depth. In contrast, the abundances of MCG and SAGMEG increased from $10 \%$ to $40 \%$ and 0 to $30 \%$ moving towards the downcore of CL11, respectively. However, the relative abundance of sequences corresponding to MGI was the dominant group from 17 to $364 \mathrm{cmbsf}$. The methane-oxidizing archaea are usually the dominant groups distributed in the sulfatemethane-transition zone (LEE et al 2013); however, for unknown reasons we only detected low abundances of ANME-1 in this zone.

\section{DISCUSSION}

\section{Microbial cellular abundance and affecting factors}

Previous studies indicated that cell abundance determined with AODC could provide a broad overview of the distribution of microorganisms in the sediments (PARKES et al 2000). Total cell number ranged from $10^{8}$ to $10^{9}$ cells $/ \mathrm{cm}^{3}$ in sediments near the surface, and declined with depth in the sediment column (D'HONDT et al 2004), but showed variation with the different environments. The bacterial cell abundance was estimated to range from $10^{5}-10^{8}$ cells/g in sediments in continental slope or deep sea sediments from the SCS (ZHANG et al 2012; JIAO et al 2015; JIANG et al 2007). It was inferred that variations of microbial abundance in marine sediments might relate to concentrations of intact phospholipids and TOC (LIPP et al 2008). The microbial cellular abundance in sediments of Core CL11 was $10^{7}$ cells/g, which was higher than both the $10^{6}$ cells/g measured in abyssal (collected at about $3000 \mathrm{~m}$ water depth) cold seep sediment with $0.5 \%$ TOC of the northeastern SCS (ZHANG et al 2012). Our data is similar with the result from Qiongdongnan Basin, in which the cell number was $10^{7}$ cells/g in sediments with $0.84 \%$ to $1.2 \%$ TOC (JIANG et al 2007). Downcore microbial cell abundance showed that relatively higher bacteria abundance was detected at depths of $350 \mathrm{cmbsf}$ and $720 \mathrm{cmbsf}$, which is not consistent considering the TOC content. It was inferred that the bacterial cell abundance might be related to the porosity of sediments and methane supply. With $2.06 \%$ sand fraction at a depth of $350 \mathrm{cmbsf}$ was measured. It can be inferred that sediment porosity increased with the increased sand fraction, resulting in a possible increase of fluid or energy supply in the sediments. Similar evidence was found in sediments at Integrated Ocean Drilling Site C0006, Nankai Trough, where cell abundance increased in the sand interval (about from $30 \mathrm{cmbsf}$ to $75 \mathrm{mbsf}$ ) (EXPEDITION 316 SCIENTISTS), whereas TOC content was relatively low in those intervals. Methane is a very important factor in cold seep areas and plays a vital role in chemical cycling. Previous studies indicate strong correlations between downcore variations of microbial cellular abundance and methane concentrations in cold seep sediment, as well as in sediments containing gas hydrates (ZHANG et al 2012). The relative higher bacterial cell abundance at the depth of $700 \mathrm{cmbsf}$ was inferred to be related with a higher methane concentration. However, a relative lower bacterial cell abundance was detected in SMTZ, which is inconsistent with higher methane-oxidizing microbial activity.

\section{Archaeal community variation and geobiochemical reactions}

The archaeal communities in cold seep sediments from the SCS were compared with those in other world oceans. A slight shift of community composition was observed, indicating that unique archaeal communities exist in various cold seeps around the world oceans. Halobacteria and MBG-B were dominant archaeal communities in the abyssal cold seep at a water depth of 3,000 mbsf in Core DSH1 (ZHANG et al 2012). However, MGI and ANME archaeal groups were dominant in cold seep surface sediments from the Nankai Trough along the western margin of the Pacific Ocean (ARAKAWA et al 2006). In the Gulf of Mexico hydrocarbon seep, Methanosarcinales, ANME-1, Thermoplasmales and Methanomicrobiales were found to be dominant (MILLS et al 2003), and ANME was the dominant group in the Sonora Margin cold seeps in Guaymas Basin (Gulf of California) (VIGNERON et al 2013).

Archaeal community composition and distribution analyses showed that MBG-B was widely distributed across all the depths of the Core CL11. Previous studies showed that MBG-B occurred in a wide range of sampling sites and sediment types (TESKE et al 2008). Originally, MBG-B were detected in surface sediments on the continental slope and abyssal plain of the North Atlantic (VETRIANI et al 1999) and hydrothermal vent sites (TAKAI et al 1999), then in deep sea sediments in hydrate zones at 
Nankai Trough and the Peruvian continental shelf (REED et al 2002; SØRENSEN et al 2006). MBG-B was also the dominant group in the hydrate-bearing sites of the Cascadia and Peru Margins; as well as in the sulfate reducing zone in shallow sediments above gas hydrates (INAGAKI et al 2006). It was suggested that MBG-B might play an important role in the biogeochemical processes of sulfate reduction and methane oxidation (BIDDLE et al 2006). Although there is limited knowledge about the metabolic functions of the MBG-B group, the recognition of microbial populations that consistently occur in the presence of methane hydrates probably serves as a starting point for defining their ecological and biogeochemical significance (INAGAKI et al 2006). Our data also showed that MCG and SAGMEG were also dominant groups, with both of them increasing in abundance with depth. MCG live in diverse habitats, including terrestrial and marine, hot and cold, surface and subsurface environments (BIDDLE et al 2006; KUBO et al 2012). Although this group was frequently observed to be abundant, diverse and widespread in marine sediments (KUBO et al 2012), it seems unlike the methanotrophs to utilize methane for energy. Biddle et al. (2006) suggested that the MCG dominated sediment horizons indicated that MCG utilized the buried organic carbon and likely a group of heterotrophic archaea to assimilate complex organic substrates. The archaeal group of SAGMEG was also another predominant group in the Core CL11, which slightly increased in abundance with the elevated methane concentration. Previous studies showed that SAGMEG appeared to be a metabolically active archaeal group in deep marine subsurface sediments (SØRENSEN et al 2006) and might prefer living in methane rich or gas hydrate zones, as it was commonly found in deep marine sediments containing methane hydrates in the Nankai Trough (REED et al
2002). The SMTZ is a general feature of marine sediments and is thought to be associated with microbial activities with anaerobic oxidation of methane coupled with sulfate reduction driven by bacteria. An analysis of the current data set for the $16 \mathrm{~S}$ rRNA genes of the ANME groups indicates that their occurrence is limited to the upper few meters of subsurface sediments, as no genes have been retrieved from any deep biosphere core yet (KNITTEL et al 2005), which is very similar with our result obtained from the Core CL11.

\section{CONCLUSIONS}

The abundance of total bacterial cell number and the archaeal 16S rRNA gene copies were associated with either the sediment texture or methane concentration in the Core CL11.

The Illumina sequencing result showed the community was predominantly comprised of Crenarchaeota and Eurarchaeota. MBG-B, MCG and SAGMEG were the dominant groups across the seven sediment depths, and a slight shift of community composition was observed at increased depths.

The data in this study will add to the knowledge of the archaeal community composition and enhance our understanding of their possible roles in geochemical processes in the cold seep sediments of the northern SCS.

\section{ACKNOWLEDGEMENTS}

The authors acknowledge James Hurley at the University of Colorado for making a critical reading a nd revision of this paper. This research was supported by the China Geological Survey "National Gas Hydrate Exploration and Production Major Project" (Grant No. GZH201100305-06-02).

RESUMO: O recife de metano de Jiulong, uma grande área de emanação fria no talude continental do Mar da China Meridional - SCS, foi caracterizado através da fauna quimiossintética, dos tapetes bacterianos, estruturas de carbonato derivadas do metano, e por perfis de sedimentos de pouca profundidade na zona de transição de sulfato-metano , SMTZ, coletados por gravity corer (testemunhador à gravidade). De modo a caracterizar a diversidade microbiana e a variação na correlação com a emanação fria de metano na área, a comunidade archaeal nos sedimentos do perfil CL11 foi analisada, usando o sistema de sequenciamento Illumina MiSeq. Um total de 96.917 sequências válidas foram obtidas e classificadas em 275 OTUs. As análises taxonômicas mostraram que todas as sequências archaeais pertenciam aos filos Crenarchaeota(69.41\%) and Eurarchaeota (25.26\%). A distribuição vertical das comunidades archaeal mostrou que o Grupo Bêntico Marinho B (Marine Benthic Group B, MBG-B) foi o grupo predominante (58,92\%) no sedimento da extremidade superior do core, enquanto que porcentagens das sequências do South African Gold Mine Euryarchaeotal Group (SAGMEG) aumentaram com a profundidade. Os nossos resultados indicam que a comunidade archaeal na emanação fria do recife de metano de Jiulong é única e nos fornece novas perspectivas a respeito da composição da comunidade archaeal na área de emanação fria.

PALAVRAS-CHAVE: Profundidade. Diversidade. Zona de transição sulfato-metano. 


\section{REFERENCES}

ARAKAWA, S.; SATO, T.; YOSHIDA, Y.; USAMI, R.; KATO, C. Comparison of the microbial diversity in cold-seep sediments from different depths in the Nankai Trough. The Journal of General and Applied Microbiology, v. 52, n. 1, p. 47-54, 2006. http://dx.doi.org/10.2323/jgam.52.47

AMATO, K. R.; YEOMAN, C. J.; KENT, A.; RIGHINI, N.; CARBONERO, F.; Estrada, A., et al. Habitat degradation impacts black howler monkey (Alouatta pigra) gastrointestinal microbiomes. The ISME Journal, v. 7, n. 7, p. 1344-1353, 2013. http://dx.doi.org/10.1038/ismej.2013.16

BOTTOMLEY, P. J. Light microscopic methods for studying soil microorganisms. Methods of Soil Analysis, part 2, p. 81-105, 1994. http://dx.doi.org/10.2136/sssabookser5.2.c6

BAKER, G. C.; SMITH, J. J.; COWAN, D. A. Review and re-analysis of domain-specific 16S primers. Journal of Microbiological Methods, v. 55, n. 3, p. 541-555, 2003.

http://dx.doi.org/10.1016/j.mimet.2003.08.009

BIDDLE, J. F.; LIPP, J. S.; LEVER, M. A.; LLOYD, K. G.; SØRENSEN, K. B.; ANDERSON, R., et al. Heterotrophic archaea dominate sedimentary subsurface ecosystems off Peru. Proceedings of the National Academy of Sciences of the United States of America, v. 103, n. 10, p. 3846-3851, 2006.

http://dx.doi.org/10.1073/pnas.0600035103

Delong, E. F. Archaea in coastal marine environments. Proceedings of the National Academy of Sciences of the United States of America, v. 89, n. 12, p. 5685-5689, 1992. http://dx.doi.org/10.1073/pnas.89.12.5685

D'HONDT, S.; JØRGENSEN B. B.; MILLER, D. J.; BATZKE, A.; BLAKE, R.; CRAGG, B. A., et al. Distributions of microbial activities in deep subseafloor sediments. Science, v. 306, n. 5705, p. 2216-2221, 2004. http://dx.doi.org/10.1126/science.1101155

DENG, X. G.; FU, S. Y.; HUANG, Y. Y.; ZHANG, G. X.; WU, N. Y.; WU, L. S. Geochemical Characteristics of Sediments at Site HD196 in Dongsha Islands, the North of the South China Sea, and Their Implication for GasHydrates. Geoscience (China), v. 20, n. 1, p. 92-102, 2006.

Expedition 316 Scientists. Expedition 316 Site C0006, Investigations of Seismogenesis, Nankai Trough, Japan. Ocean Drill Program, 314/315/316, 2009.

INAGAKI, F., NUNOURA, T.; NAKAGAWA, S.; TESKE, A.; LEVER, M.; LAUER, A., et al. Biogeographical distribution and diversity of microbes in methane hydrate-bearing deep marine sediments on the Pacific Ocean Margin. Proceedings of the National Academy of Sciences of the United States of America, v. 103, n. 8, p. 2815-2820, 2006. http://dx.doi.org/10.1073/pnas.0511033103

JIANG, H. C.; DONG, H. L.; JI, S. S.; YE, Y.; WU, N. Y. Microbial diversity in the deep marine sediments from the Qiongdongnan Basin in South China Sea. Geomicrobiology Journal, v. 24, n. 6, p. 505-517, 2007. http://dx.doi.org/10.1080/01490450701572473

JIAO, L.; SU, X.; WANG, Y.; JIANG, H.; ZHANG, Y.; CHEN, F. Microbial diversity in the hydratecontaining and -free surface sediments in the Shenhu area, South China Sea. Geoscience Frontiers, v. 6, n. 4, p. 627-633, 2015. http://dx.doi.org/10.1016/j.gsf.2014.04.007

KNITTEL, K.; LÖSEKANN, T.; BOETIUS, A.; KORT, R.; AMANN, R. Diversity and distribution of methanotrophic Archaea at cold seeps. Applied and Environmental Microbiology, v. 71, n. 1, p. 467-479, 2005. http://dx.doi.org/10.1128/AEM.71.1.467-479.2005

KAMANN, P. J.; RITZI, R. W.; DOMINIC, D. F.; CONRAD, C. M. Porosity and permeability in sediment mixtures. Groundwater, v. 45, n. 4, p. 429-438, 2007. http://dx.doi.org/10.1111/j.1745-6584.2007.00313.x 
KUBO, K.; LLOYD, K. G.; BIDDLE, J. F.; AMANN, R.; TESKE, A.; KNITTEL, K. Archaea of the Miscellaneous Crenarchaeotal Group are abundant, diverse and widespread in marine sediments.

The ISME journal, v. 6, n. 10, p. 1949-1965, 2012. http://dx.doi.org/10.1038/ismej.2012.37

LIPP, J. S.; MORONO, Y.; INAGAKI, F.; HINRICHS, K. U. Significant contribution of Archaea to extant biomass in marine subsurface sediments. Nature, v. 454, n. 7207, p. 991-994, 2008.

http://dx.doi.org/10.1038/nature07174

LEE, J. W.; KWON, K. K.; AZIZI, A.; OH, H. M.; KIM, W.; BAHK, J. J. Microbial community structures of methane hydrate-bearing sediments in the Ulleung Basin, East Sea of Korea. Marine and Petroleum Geology, v. 47, p. 136-146, 2013. http://dx.doi.org/10.1016/j.marpetgeo.2013.06.002

http://dx.doi.org/10.1016/j.marpetgeo.2013.06.003 http://dx.doi.org/10.1016/j.marpetgeo.2013.04.006

MILLS, H. J.; HODGES, C.; WILSON, K.; MACDONALD, I. R.; SOBECKY, P. A. Microbial diversity in sediments associated with surface-breaching gas hydrate mounds in the Gulf of Mexico. FEMS Microbiology Ecology, v. 46, n. 1, p. 39-52, 2003. http://dx.doi.org/10.1016/S0168-6496(03)00191-0

MA, L.; MO, X. W.; LU, J. A.; SHA, Z. B.; LIANG, J. Q. Log Interpretation of Natural Gas Hydrate and Its Case History in South China Sea. Well Logging Technology (China), v. 37, n. 3, p. 627-633, 2013.

PAULL, C. K.; HECKER, B; COMMEAU, R. FREEMAN-LYNDE, R. P.; NEUMANN, C.; CORSO, W. P., et al. Biological communities at the Florida escarpment resemble hydro-thermal vent taxa. Science, v. 226, n. 4677, p. 965-967, 1984. http://dx.doi.org/10.1126/science.226.4677.965

PARKES, R. J.; CRAGG, B. A.; Wellsbury, P. Recent studies on bacterial populations and processes in subseafloor sediments: a review. Hydrogeology Journal, v. 8, n. 1, p.11-28, 2000.

http://dx.doi.org/10.1007/PL00010971

REED, D. W.; FUJITA, Y.; DELWICHE, M. E.; BLACKWELDER, D. B.; SHERIDAN, P. P.; UCHIDA, T.; COLWELL, F. S. Microbial communities from methane hydrate-bearing deep marine sediments in a forearc basin. Applied and Environmental Microbiology, v. 68, n. 8, p. 3759-3770, 2002.

http://dx.doi.org/10.1128/AEM.68.8.3759-3770.2002

SUESS, E. RV SONNE cruise report SO 177, Sino-German cooperative project, South China Sea Continental Margin: geological methane budget and environmental effects of methane emissions and gas hydrates. IFMGEOMAR Reports, 133pp, 2005.

SU, X.; CHEN, F.; YU, X. H.; HUANG Y. A pilot study on Miocene through Holocene sediments from the continental slope of the South China Sea in correlation with possible distribution of Gas Hydrates. Geoscience (China), v. 19, n. 1, p. 1-13, 2005.

SØRENSEN, K. B.; TESKE, A. Stratified communities of active archaea in deep marine subsurface sediments. Applied and Environmental Microbiology, v. 72, n. 7, p. 4596-4603, 2006.

http://dx.doi.org/10.1128/AEM.00562-06

SCHLOSS, P. D.; WESTCOTT, S. I.; RYABIN, T.; HALL, J. R.; HARTMANN, M.; HOLLISTER, E. B., et al. Introducing mothur: open-source, platform-independent, community-supported software for describing and comparing microbial communities. Applied and Environmental Microbiology, v. 75, n. 23, p. 7537-7541, 2009. http://dx.doi.org/10.1128/AEM.01541-09

TAKAI K.; HORIKOSHI, K. Genetic diversity of archaea in deep-sea hydrothermal vent environments. Genetics, v. 152, n. 4, p. 1285-1297, 1999.

TESKE, A.; SØRENSEN, K. B. Uncultured archaea in deep marine subsurface sediments: have we caught them all?. The ISME Journal, v. 2, n. 1, p. 3-18, 2008. http://dx.doi.org/10.1038/ismej.2007.90 
VETRIANI, C.; JANNASCH, H. W.; MACGREGOR, B. J.; STAHL, D. A.; REYSENBACH, A. L. Population structure and phylogenetic characterization of marine benthic Archaea in deep-sea sediments. Applied and Environmental Microbiology, v. 65, n. 10, p. 4375-4384, 1999.

VIGNERON, A.; CRUAUD, P.; PIGNET, P.; CAPRAIS, J. C.; CAMBON-BONAVITA, M. A.; Godfroy, A.; Toffin, L. Archaeal and anaerobic methane oxidizer communities in the Sonora Margin cold seeps, Guaymas Basin (Gulf of California). The ISME journal, v. 7, n. 8, p. 1595-1608, 2013.

http://dx.doi.org/10.1038/ismej.2013.18

WASMUND, K.; KURTBÖKE, D. I.; BURNS, K. A.; BURNS, K. A.; BOURNE, D. G. Microbial diversity in sediments associated with a shallow methane seep in the tropical Timor Sea of Australia reveals a novel aerobic methanotroph diversity. FEMS Microbiology Ecology, v. 68, n. 2, p. 142-151, 2009.

http://dx.doi.org/10.1111/j.1574-6941.2009.00667.x

Zhang, Y.; Su, X.; Chen, F.; Wang, Y.; Jiao, L.; Dong, H., et al. Microbial diversity in cold seep sediments from the northern South China Sea. Geoscience Frontiers, v. 3, n. 3, p. 301-316, 2012.

http://dx.doi.org/10.1016/j.gsf.2011.11.014 